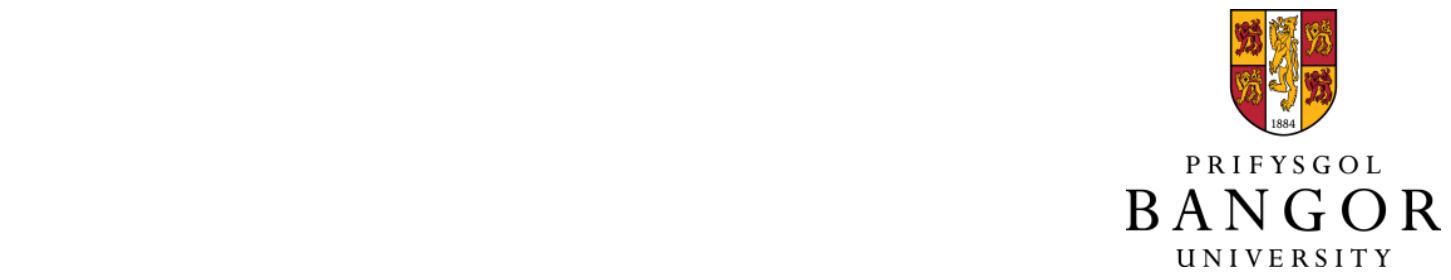

Moving Shakespeare: La danse narrative and adapting to the Bard Hiscock, Andrew

\title{
Cahiers Elisabéthains
}

Published: 20/07/2020

Peer reviewed version

Cyswllt i'r cyhoeddiad / Link to publication

Dyfyniad o'r fersiwn a gyhoeddwyd / Citation for published version (APA):

Hiscock, A. (2020). Moving Shakespeare: La danse narrative and adapting to the Bard. Cahiers Elisabéthains, 102(1), 18-37. https://doi.org/10.1177/0184767820914513

\footnotetext{
Hawliau Cyffredinol / General rights

Copyright and moral rights for the publications made accessible in the public portal are retained by the authors and/or other copyright owners and it is a condition of accessing publications that users recognise and abide by the legal requirements associated with these rights.

- Users may download and print one copy of any publication from the public portal for the purpose of private study or research.

- You may not further distribute the material or use it for any profit-making activity or commercial gain

- You may freely distribute the URL identifying the publication in the public portal ?
}

Take down policy

If you believe that this document breaches copyright please contact us providing details, and we will remove access to the work immediately and investigate your claim. 


\section{Moving Shakespeare: la danse narrative and adapting to the Bard}

Andrew Hiscock

Bangor University/Institut de Recherche pour la Renaissance, l'Âge Classique et les

Lumières, Université Paul-Valéry Montpellier 3

School of English Literature

New Main Arts Building

College Road

Bangor University

Bangor

Gwynedd

Wales LL57 2DG

Email -a.hiscock@bangor.ac.uk

\section{Abstract}

This article considers the expectations of narrative which frequently surround the Shakespearean dance adaptation. Reviewing responses to two contemporary productions (Le Songe by Les Ballets de Monte Carlo and Golden Hours (As You Like It) by the Rosas company), discussion pays particular attention to critical and audience appetites when attending performances of Shakespeare on the dance stage. Highlighting contemporary debates in dance studies, the discussion draws to a close examining the challenges of transposing (often well-known) Shakespearean texts into bodily gesture and movement.

\section{Keywords}

Shakespearean dance adaptation, Jean-Christophe Maillot, Anne Teresa de Keersmaeker, Le Songe, Golden Hours (As You Like It), dance criticism

\section{Résumé}

Cet article examine les attentes de la narrative qui accompagnent fréquemment l'adaptation des textes shakespeariens à la danse. Passant en revue les réponses à deux spectacles contemporains (Le Songe des Ballets de Monte-Carlo et Golden Hours (As You Like It) de la compagnie Rosas), la discussion porte une attention particulière aux appétits des critiques et du grand public lors des représentations de Shakespeare à travers la danse. Mettant en relief les débats contemporains dans la critique de danse, la discussion se termine en examinant les défis de la traduction des textes shakespeariens (souvent bien connus) dans le vocabulaire de la gestuelle du corps.

\section{Mots clés}

Adaptation des textes shakespeariens à la danse, Jean-Christophe Maillot, Anne Teresa de Keersmaeker, Le Songe, Golden Hours (As You Like It), critique de danse 


\title{
Moving Shakespeare: la danse narrative and adapting to the Bard
}

\author{
Andrew Hiscock
}

A well-composed ballet is a living picture of the passions, manners, customs and ceremonies of all nations of the globe, consequently it must be expressive in all its details and speak to the soul through the eyes; if it be devoid of expression, of striking pictures, of strong situations, it becomes a cold and dreary spectacle. This form of art will not admit of mediocrity ${ }^{1}$

The choreographer and dance theorist Jean-Georges Noverre (1727-1810) remained in no doubt in the mid-eighteenth century that the highest expressions of the art of dance lent themselves effortlessly to social and spiritual communication, unimpeded by questions of language, geography or nation. For Noverre, such superlative forms of communication were linked intimately to what he termed the ballet d'action or, what is more frequently known in the modern period as, ballet narratif. For the bringing to fruition of such projects, Noverre insisted upon a paring down of dance performance: 'Not a single, unnecessary personage should appear to the spectator, consequently the stage should be denuded of everything likely to retard the action'. In addition, he postulated the ideal of the ballet d'action in explicitly dramaturgical terms: the ballet should be divided into scenes and acts and 'each scene should possess, like the act, a beginning, central portion and conclusion; that is to say, its introduction, plot, and climax'.2

The present discussion concentrates precisely upon these very questions highlighted by Noverre in the eighteenth century. Focusing on two contemporary Shakespearean adaptations, Golden Hours (As You Like It) by Anne Teresa de Keersmaeker's Rosas company and Jean-Christophe Maillot's Le Songe (an interpretation of A Midsummer Night's Dream) performed by Les Ballets de Monte Carlo, this analysis interrogates expectations, which have traversed the generations, concerning the potential and/or imperative of dance to inspire affective response in audiences and to offer them legible narrative progression. Strikingly, Noverre's idealist aspirations for the ballet continue to have currency into the modern period. Sondra Horton Fraleigh, for example, defines the artform as 'movement that has undergone some meaningful transformation. It is thus that it holds the transformational power to move us beyond self and beyond the ordinary'. ${ }^{3}$ Elsewhere, working a similar vein, Randy Martin emphasises dance's propensity to prise us away from the thrall of our everyday lives: 'Dance treats the mobilization of bodies more reflexively than quotidian bodily acts'. ${ }^{4}$ Indeed, these points had been taken up in the closing years of the twentieth century by the internationally celebrated dancer, choreographer, company director and impressario Maurice Béjart. During a visit to Tokyo in February 1996, he went further than Noverre, proposing that, in the most potent expression of their work, great artists from all disciplines displayed the ability to 
dépasser leur art, de réunir en eux toutes les possibilités, d'exploser dans les limites d'une seule technique pour rejoindre le fondement de la créativité universelle. Léonard de Vinci est un des prototypes de semblables explosions. Shakespeare est beaucoup plus qu'un auteur dramatique. Picasso va plus loin que la peinture avec ses moyens de peintre. Orson Welles comme Molière dépassent le théâtre et le cinéma. ${ }^{5}$

This same insistence upon arts of all kinds extending themselves into extraordinary achievement, into awe-inspiring creativity, feeds a larger concern in this discussion with respect to the abiding expectations of dance to engender change and revelation in both emotional and epistemological terms - expectations which Noverre had promoted over two hundred years earlier and which clearly persist into the present. Indeed, the critic Elizabeth Dempster, for example, argues that 'The governing logic of modern dance is not pictorial, as in the ballet, but affective'. ${ }^{6}$

Golden Hours (As You Like It) formed part of the 2015 Montpellier Danse programme. It was performed by the Belgian Rosas company (a group of eleven early career dancers in this instance) and choreographed by Anne Teresa de Keersmaeker. Dancing to the 1975 Brian Eno score 'Another Green World' (arranged by Carlos Garbin, also one of the company's dancers), Rosas had premièred this production in January 2015 in Brussels at the Théâtre Royal de la Monnaie, before touring with it to Paris, London, Graz, Lille, Bruges and then to Montpellier Danse (summer 2015). Le Songe, an interpretation of A Midsummer Night's Dream, was performed by Les Ballets de Monte Carlo at the Shake-Nice festival hosted at the Théâtre National de Nice in January 2017. Choreographed by Jean-Christophe Maillot (directing the company since 1993), this production, with musical arrangements by Mendelssohn, Daniel Teruggi and Bertrand Maillot, was already well-established in the company's repertoire by January 2017, having been premièred in 2005. The contexts for these productions were thus qualitatively different: the Rosas company offered Golden Hours (As You Like It) within the programme of an established festival (Montpellier Danse) devoted annually to contemporary dance performance. On the other hand, the performance of Le Songe took place within the programme of an annual festival (Shake-Nice) devoted not only to Shakespeare, but also primarily to theatrical productions of his works.

In terms of institutional memory, Les Ballets de Monte Carlo looks to origins in the early twentieth century when Diaghelev established a base for the Ballets Russes in Monaco. Indeed, there are interesting parallels here with De Keersmaeker's longstanding collaboration with the Théâtre Royal de la Monnaie in Brussels which has a celebrated tradition of dance performance, including paying host to Maurice Béjart's Ballet du XX ${ }^{\text {me }}$ siècle company during the extended period 1960-87.7 Béjart himself continued to explore the possibility of Shakespearean dance adaptation throughout his career as a dancer, choreographer and company director. In the 1950s, for example, he founded Les Ballets romantiques, re-named subsequently, Les Ballets de l'Etoile and then Ballet Théâtre for which he created Le Songe d'une nuit d'hiver and also La Mégère Apprivoisée, for example. ${ }^{8}$ In terms of further contexts for situating Maillot's Le Songe, the repertoire of Les Ballets de Monte Carlo straddles both classical and contemporary practice. Its participation in Shake-Nice in 2017 was the first instance of its kind for a dance company in a festival which was founded very recently in 2015 by the Théâtre National de Nice's director, Irina Brook. It played in the main auditorium of the theatre 
to full audiences and brought to a close that week's programme in the festival which had included an English-language production of The Winter's Tale and a Frenchlanguage production of Timon of Athens. However, the consideration of both dance productions, which exploited variously on occasions the resources of spoken and written Shakespearean text, feeds a much larger commitment in the present discussion concerning the appetite for narrative in Shakespearean dance adaptation. The reviewer for The Figaro, for one, remained unconvinced by the recourse to speech for the performance of Le Songe in 2006: 'La gestuelle est un mélange de pantomime et de danse, auquel vient s'ajouter parfois la parole. L'ensemble est très hétérogène et ne facilite pas la compréhension'. 9 Interestingly, in this instance, reviewer discomfort may point to ongoing concerns with establishing the performative potential, and the limitations, of dance per se.

In the discussion which follows, such critical expectations are reviewed through the prism of these two contemporary productions at recent festivals in the South of France. However, more broadly, this discussion seeks to gauge the undertakings involved in adapting what is frequently perceived as the intensely word-anchored or text-oriented experience of Shakespeare's drama. Moreover, it is clear that such querying is not only being articulated in academic criticism and journalism. When interviewed, De Keersmaeker herself has enquired, 'How can a thought, intention, image, or idea that is usually uttered via the spoken word, generate movement? How do we create meaning and express what we want to communicate through movement?'. ${ }^{10}$ Thus, choreographers, audiences and critics alike are drawn to consider how (and if) dance performance might develop, supplement and/or draw further potential from sixteenth-century playscripts without necessarily engaging explicitly in la danse narrative, indeed without drawing upon resources associated with the spoken or written word.

A text such as A Midsummer Night's Dream, which has been taken up again and again since the eighteenth century in dance productions, may not pose significant difficulties in terms of generalised plot recognition among spectators. Such knowledge may have been gleaned through acquaintance with the text itself or at first- or secondhand through adaptations for the theatre, cinema, television or internet consumption. However, this may not be the case at all for the intrigue of As You Like It, where even a residual knowledge may not be securely relied upon. ${ }^{11}$ Indeed, reviewing such cultural expectations more broadly, Adam Pine and Olaf Kuhlke have underlined that

As contemporary society becomes less face-to-face and tablet, smartphones, and YouTube videos govern communication, the splintering and spatial differentiation of the audience of dance means that there is no shared knowledge system which choreographers can use to inscribe meaning of movement. ${ }^{12}$

Thus, does company decision-making surrounding textual selection among the Shakespeare corpus for dance adaptation facilitate, necessitate or impede the creation of danse narrative? Furthermore, as has been observed above, linked to this broader question of dance narratology, it is also useful to consider the status and function of the deployment of the spoken or written word - might the latter indicate the ways in which a sixteenth-century text is being extended, supplemented, re-created through movement and gesture in simultaneous or parallel diegesis or does it point to the 
parameters of the arts of expressive movement? For his part, Robin Wharton has proposed the possibility of such a crisis of execution and interpretation in Shakespearean dance adaptation whereby 'To adapt Shakespeare for the ballet stages a confrontation between the limited vocabulary of the dance form and a received cultural text that in many ways deconstructs the core identities that vocabulary has evolved to reify and maintain'. ${ }^{13}$ The tensions, stresses and strains in such critical and performative undertakings lie at the very heart of the present discussion.

\section{Dance and the Recurrence of Debate}

Critical theorizing linking dance to expectations of cognitive challenge and epiphanic experience has surrounded the art since antiquity. Lucian's treatise The Dance, written in the second century AD, for example, was deeply influenced by the Platonic belief, articulated in the Timaeus, that the universe was shaped by 'the dancing movements of [the] gods, their juxtapositions and the back-circlings and advances of their circular courses upon themselves'. ${ }^{4}$ Lucian's dialogue between the danceophile Lycinus and the cynic Crato unfolds with the latter continuing to lodge moral objections to the practice. However, his opponent ultimately triumphs, proposing 'why is not dancing a thing of utter harmony, putting a fine edge upon the soul, disciplining the body, delighting the beholders and teaching them much [...] [?]'. ${ }^{15}$

Similar interventions in the debate continued as one age succeeded another. ${ }^{16}$ Among Shakespeare's own contemporaries, the lawyer-poet Sir John Davies' 'Orchestra' (1598) had even the recalcitrant queen Penelope enthralled by the dancing organised by her would-be suitor:

So subtil and curious was the measure,

With such vnlookt for chaunge in euery straine;

As that Penelope rapt with sweet pleasure,

Weend she beheld the true proportion plaine

Of her owne webb weavd and unweavd again. ${ }^{17}$

Nonetheless, the eighteenth century is a strategic cultural moment in which to initiate this particular discussion of Shakespearean dance adaptation and danse narrative for, as Alan Brissenden has pointed out, it was in the later decades of that century that 'speech was done away with altogether, and action alone, in the form of dance, was first used to interpret Shakespeare's plays on the stage' ${ }^{18}$ As Iris Julia Bührle has stressed, Noverre is credited with choreographing the first ballet production of a Shakespeare play (Cleopatra) in 1765; and, indeed, in the mid-eighteenth century, he continued to reflect upon the narrative functions that dance might hold for the stage, working with David Garrick in London during the years 1755-57. ${ }^{19}$ This was a period in which the English actor-director-impresario prepared, amongst many other things, Shakespearean adaptations (which included dance interventions) for the London stage. In 1755, for example, Garrick's Theatre Royal in Drury Lane offered an adaptation - partly through the medium of dance - of A Midsummer Night's Dream entitled The Fairies by Christopher Smith (the Younger). ${ }^{20}$

Harold F. Brooks, a post-war editor of this Shakespearean comedy, acknowledged that 'the text of the Dream is on the shorter side, though in performance the songs and dances would lengthen it', adding that dance remains in this play 'an essential part of 
the action and the symmetric structure'. ${ }^{21}$ More generally, criticism of A Midsummer Night's Dream has recognized the pronounced status of dance in Shakespeare's dramatic narrative - indeed, Brissenden points to the fact that Shakespeare exploited the potential of dance in this play 'more abundantly than he was ever to do again'.22 Developing such insights further, Rodney Stenning Edgecombe has identified an overarching dance lexis for Shakespeare's intrigue whereby 'a good deal of A Midsummer Night's Dream is devoted to the proper alignment of the lovers' quartet which keeps breaking down into fractious triangles. In effect, the epitasis or middle part of $A$ Midsummer Night's Dream takes form as [...] a quadrille manqué. ${ }^{23}$ This particular Shakespearean comedy is thus exceptional in repeatedly drawing attention to dance in the body of its text and paratexts (both in stage direction and dialogue) to acknowledge the artform's integral role in exciting, re-enacting, reflecting upon and sometimes resolving crises embedded within the dramatic narrative. This is far from the case for all Shakespearean drama and so the undertaking of adaptation may represent challenges not only in terms of communicating that which the spoken word may principally shoulder in conventional theatre performance, but in relying upon some, perhaps indepth, audience knowledge of a given Shakespearean drama prior to performance.

More generally, on reviewing debates concerning dance since the early modern period, it is striking how often Noverre's contentions are posited and re-examined. Reading dance historically, Jennifer Nevile, for example, has underlined the ways in which dance has not only often constituted down the centuries, 'a secondary, derivative, diversionary and minor art, an art which does not generate its own meanings [...] [but] This conception of the body denies its capacity, and by extension that of dance, to allude to other realities or to create new fictions'. ${ }^{24}$ Elsewhere, Elizabeth Klett adds that this situation has become even bleaker when dance turns its attention to adaptation: 'The tendency to perceive adaptations as secondary to the so-called original; and to police the degree to which an adaptation respects the authority of that original, is especially pronounced when looking at adaptations of Shakespeare'. ${ }^{25}$ Thus, dance's sometimes perceived reliance on other arts to complete its hermeneutic undertakings remains an animated subject of debate in dance theorising more generally and, indeed, shows no signs of faltering.

\section{Dancing with the Bard}

In the description of its own production, the Rosas company insists upon the bifocal vision of Golden Hours (As You Like It), arguing that this dual emphasis remains key to accessing the performance: 'Le double titre du spectacle [...] nous en donne les clés' ${ }^{26}$ More generally, in the company's programme notes, Shakespeare's Forest of Arden is styled as 'un monde idyllique' where figures are depicted as seeking refuge from court corruption. ${ }^{27}$ However, rather than specifically conceived as adaptation, the production is described by the company as an encounter ('rencontre') between Brian Eno's music composed some forty years before and dance performance. For this production, Eno's music is heard in a loop of five repetitions. Nonetheless, a substantial part of the performance is played out with only the aural accompaniment of dancers' movements and breathing: for its London performance at Sadler's Wells the reviewer for The Financial Times underlined that 'A good half of the evening is danced in silence' ${ }^{28}$ Clearly, the production has continued to undergo some significant changes during its time in the Rosas repertoire. The Financial Times noted for the record that the London 
production was thirty minutes shorter than the Brussels première of the work in January 2015. ${ }^{29}$ Despite this, the reviewer for Cahiers Élisabéthains stressed that for Montpellier Golden Hours still expanded the evening's performance beyond the circumscribed span of Shakespeare's dramatic narrative, prompting a significant exodus of audience members prior to the close of the proceedings. $3^{30}$

More broadly, the Rosas company envisages the words of Shakespeare's text as transitioning ('emigrent') to thinking bodies ('corps pensants') and thus the performance is described as being played out in resolutely silent ('obstinément muets') terms with hands, feet and facial looks and expression. ${ }^{31}$ At points, textual extracts are projected onto surfaces to enhance the experience of a multi-medial event, but the degree to which such interventions from a text (which may not be at the audience's immediate recall) frame, explicate or counterpoint the danced performance remains open to question. In addition, Shakespeare's text makes more oblique entries in the Rosas production in terms of fragments whispered during the production by the dancers, sometimes outward to the audience, sometimes beyond our earshot. In stark contrast to the luxuriousness of the production values often in evidence for Le Songe, in Golden Hours the Rosas dancers are aligned visually with the everyday with the garb of urban sportswear - dismissed by The Financial Times reviewer as 'sweatshirts and joggings' or L'Alsace as 'les baskets, les bonnets et les sweats à capuche'. ${ }^{22}$ The uniformly subdued palate of Rosas costuming clearly sought to defy gender-marked navigation through the production, facilitating the disguised transformation of Rosalind into masculinised combatant and of Jaques being interpreted by a female member of the cast. Interestingly, such reservations concerning costuming would also be given voice in some appreciations of Le Songe: Le Figaro, for example, lamented that 'les costumes des Athéniens sont tous dans les mêmes tons gris'.33

In contrast to the production of Les Ballets de Monte Carlo, all the Rosas company is permanently onstage and the performance is uninterrupted by an interval. Conceptually, De Keersmaeker's company stresses that Golden Hours is designed to exploit the thematic (rather than narrative) thrust of As You Like It. Thus, misunderstanding, erotic disorientation, gaming, impersonation, madness are evoked onstage rather than a detailed account of Shakespeare's intrigue. Conversely, Maillot's Le Songe offers clearly signalled narrative developments in its three dance worlds of the Mechanicals, the Athenians and the Fairies. Moreover, whereas Le Songe is frequently viewed in purpose-built theatrical spaces such as Monaco's Grimaldi Forum, Paris's Théâtre de Chaillot, or Barcelona's Teatre del Liceu, Golden Hours (As You Like It) has been staged in more diverse settings. This may indeed, on occasions, contribute further to the challenging of audience expectations: Golden Hours is not uniformly, or perhaps reassuringly, framed within a proscenium arch in all venues - and, as Merce Cunningham underlined, 'If you don't divide a space classically, the space remains more ambiguous and seems larger'. 34

The opulent staging of Le Songe by Les Ballets de Monte Carlo was premièred in December 2005 in Monaco, drawing upon the extensive resources of the Monte Carlo Philharmonic Orchestra to musical advantage. The company director and choreographer Jean-Christophe Maillot had previously been a leading dancer in the Ballet de Hambourg (1978-83). The American John Neumeier had joined the latter company as director and choreographer in 1973 and created a sequence of Shakespearean dance adaptations for this and other companies during this period: 
Romeo and Juliet (1971), A Midsummer Night's Dream (1977), Othello (1985), As You Like It (1985), Hamlet (1985). During his time in the Hamburg company, Maillot danced in the production of A Midsummer Night's Dream and this transition from dancer to choreographer of Le Songe has been highlighted by a number of reviewers. ${ }^{35}$ Le Figaro, for example, stressed that 'Jean-Christophe Maillot s'est attaqué à un ballet difficile, le Songe d'une nuit d'été. Tâche d'autant plus délicate que l'un de ses collègues, John Neumeier, s'y était déjà attelé pour en faire un petit bijou' ${ }^{36}$

Maillot's Le Songe, which draws upon familiar classical (as well as minimalist and brutalist) musical scoring and exploits familiar balletic tropes of virtuouso, pas de deux and corps de ballet performances, has often been extremely warmly received by audiences and critics internationally. Le Monde, for example, found that 'pour vérifier une bonne fois sa capacité à tramer de fort épatantes narrations dansées - un talent devenu un label —, Jean-Christophe Maillot n'y va pas de main morte [avec Le Songe]'.37 Choreographed for twenty-six dancers (over double the size of the cast for Golden Hours), this Shakespearean dance adaptation continues to emphasise high production values with a visual and musical feast organised around the three narrative and musical worlds of the Athenians, the Fairies and the 'Mechanicals' (or 'artisans'). As many of the responses to this production have emphasised, a key organising principle for the performance is the division of Shakespeare's narrative into three sound worlds - that of the Athenians and their lovers accompanied by the music of Mendelssohn; that of the world of the fairies scored by Daniel Teruggi; and that of the mechanicals scored by Bertrand Maillot. Strikingly, in the latter world, narrative progression is also assisted by extracts of Shakespearean text spoken in English and often over-pronounced in a form of burlesque mimicry. The sets, costumes and some of the theatre props (such as Puck's sometimes mechanised perambulations around the stage) frequently serve to captivate audience attention and supplement engagement with the dance. Indeed, the costuming of the mechanicals, for example, is clearly influenced by the Cubist productions of the Ballets Russes from the early twentieth century. Unlike Golden Hours (As You Like It), projections onto surfaces are not used for narrative purposes in Maillot's production; in Le Songe this kind of additional orientation is made available through costuming and musical accompaniment.

\section{Responding to the Dance}

Reviewing the reception of dance among audiences across early modern Europe, Margaret M. McGowan justly underlines that 'Dance could never be considered in isolation. Without an audience, it had no real existence. Spectators anticipated entertainment, pleasure and the rare treat of being astonished. Their reaction, their approval were integral parts of the performance'. ${ }^{8}$ Shakespeare's contemporary Ben Jonson stressed in his masque Pleasure Reconciled to Virtue (1618) that 'dancing is an exercise/Not only shows ye mover's wit/But maketh the beholder wise,/As he hath power to rise to it'. ${ }^{39}$ Moreover, this crucial relationship of onlooker to performer has remained a source of abiding critical interest as one century has succeeded another. In the modern period, Emmanual Lévinas considered this interaction in broad philosophical terms relating to the promptings of moral responsibility inherent in all forms of 'beholding' in the human condition: 
Le spectateur est acteur. La vision ne se réduit pas à l'accueil du spectacle; simultanément, elle opère au sein du spectacle qu'elle accueille. [...] Nous ne sommes pas sujet du monde et partie du monde de deux points de vue différents, mais, dans l'expression, nous sommes sujet et partie à la fois. Percevoir, c'est, à la fois, recevoir et exprimer, par une espèce de prolepsie. ${ }^{40}$

Striking an analogous note, but with particular emphasis upon our consumption of the creative industries, Jacques Rancière more recently submitted that, 'Il nous faut donc un autre théâtre, un théâtre sans spectateurs [...] Drame veut dire action. Le théâtre est le lieu où une action est conduite à son accomplissement par des corps en mouvement face à des corps vivants à mobiliser'. ${ }^{41}$

Importantly, it remains apparent right from the period when Shakespeare's Elizabethan comedies were composed and produced for the stage that dance literacy itself could be counted upon among sixteenth-century audiences..$^{42}$ In Much Ado About Nothing, for example, the heroine Beatrice assumes the role of comic pedagogue to Hero, but her intervention would be futile on- and off-stage if her auditors had no knowledge of contemporaneous dance culture: she represents 'wooing, wedding, and repenting [...] as a Scotch jig, a measure, and a cinque pace: the first suit is hot and hasty, like a Scotch jig, and full as fantastical; the wedding, mannerly-modest, as a measure, full of state and ancientry; and then comes repentance and, with his bad legs, falls into the cinque pace faster and faster, till he sink into his grave' (2.1.61-7). Furthermore, even in the final decade of the final Tudor monarch's reign, the French emissary André Hurault de Maisse reported back in 1597 to Henri IV that Elizabeth herself laid claim to the multiple identities of dancer, choreographer, instructor and spectator:

[the queen] takes great pleasure in dancing and music. She told me [...] in her youth she danced very well, and composed measures and music, and had played them herself and danced them. She takes such pleasure in it that when her Maids dance she follows the cadence with her head, hand and foot. She rebukes them if they do not dance to her liking, and without doubt she is a mistress of the art, having learnt in the Italian manner to dance high. She told me that they called her 'the Florentine'. ${ }^{43}$

However, as responses to Golden Hours and Le Songe indicate, various audiences (and audience members) may react quite differently to a given performance, and criticism needs constantly to extend itself to encompass the varietas of spectator engagement.

Addressing this question in the mid-twentieth century, Edwin Denby highlighted that

In a dance ballet there is a difference in the way the audience watches the movement. It does not identify the gestures with reference to real life, it does not search in each pose for a distinct descriptive allusion. It watches the movements in sequence as a dance. There is a sort of suspension in judgement, a wait and a wonder till the dance is completed, till the dancer has come to rest. 44

Clearly, a critical discourse which refers to the audience as a single body ('it') having uniform responses remains problematic. Nonetheless, Denby not only pointed justly to 
the imponderables of fully accounting for audience reception, but spoke to the possibility that dance appreciation gravitates towards the habits of the linear reading experience. More recently, in line with a number of critical voices, rather than positing an overarching logic, Randy Martin has elected to foreground indeterminacy in attempting to evaluate audience engagement:

The genealogy of audience [...] is much more difficult to trace than is that of the performers. Like the latter, it is occasioned by and enables the performance, but unlike the dancers, whose specific unity as a company has a prior history, the audience in attendance is constituted only by that particular instance of the dance. ${ }^{45}$

The multifarious potential of and contrary motions in audience reception is amply exemplified in responses to Golden Hours (As You Like It) and Le Songe.

Reviewing the production at the Sadler's Wells Theatre in London, for example, the reviewer for The Guardian drew attention not only to De Keersmaeker's commitment to contemporary dance through popular music ('Have you ever tried to dance to Anton Webern?'), but also her sustained turning away from precisely narrativised performance: 'Yet in Golden Hours, De Keersmaeker is far from having a late conversion to plot'. ${ }^{6}$ In this context, it is interesting to note that for the 2015 première of the work in Brussels, The New York Times reviewer insisted rather glumly that, 'The words projected on the sides of the stage clue us into the actions and interactions, which would otherwise be impossible to decipher'. ${ }^{47}$ This seemingly insuperable challenge of interpretation posed by Golden Hours was reiterated by the reviewer for the French newspaper L'Alsace. The latter addressed precisely the thwarted expectations of a clearly delineated Shakespearean intrigue to be danced onstage:

on imaginait assister à un ballet narratif [...] C'était bien mal le connaître. On nous prévient au préalable de bien lire l'argument de la pièce. Ce conseil judicieux prend tout son sens au fur et à mesure de la soirée. [...] sans doute les spectateurs [...] qui ont quitté la salle par flots n'avaient-ils pas suivi cette consigne. ${ }^{48}$

Here, interestingly, it was reported that audiences were being advised explicitly to perform the labours of homework before attending the performance. Equally importantly, this reviewer still looked for further narrative guidance in the production itself. The critic Philippe Guisgand has strategically underlined that 'depuis sa première creation, De Keersmaeker utilise un vocabulaire dansé controversé'. ${ }^{49}$ Nonetheless, looking to Golden Hours to provide a recognizable arc of Shakespearean plot development ('cette histoire de marivaudage') for Francophone audiences, the reviewer for L'Alsace felt that the production squandered, rather than rewarded the audience's time and energy invested in it: 'Bienheureux qui aura compris qui interprétait Rosalinde [...] Bienheureux qui aura compris pourquoi elle invoque Eno [...] Mais le silence après Eno est-il encore du Eno?'.50

Back on the other side of the Channel, the reviewer for London's The Financial Times felt similarly starved of Shakespearean narrative in the Sadler's Wells production: 
The 72-page programme explains how the dancers worked out their moves with the memorised text running through their heads. Unfortunately, apart from a few leadenly literal gestures - cuckolds' horns, sheets of poetry flying about character and plot remain obscure, necessitating the liberal use of surtitles to keep the audience up to speed [...] the witty interplay of Shakespeare's lord and lovers is reduced to a po-faced game of tag..$^{1}$

Interestingly, the complaint voiced here concerning the '72-page programme' required to decipher the dance production is merely one of the most recent examples of an ongoing polemic concerning the relation of movement, adaptation and source text which has persisted down the centuries. As Bührle underlines, in the eighteenth century Noverre himself 'was often criticised for the extensive programmes he wrote which were needed to understand his ballets'..$^{2}$

Conversely, Le Songe builds upon an extremely well-established balletic lexis in visual, dance and musical terms and played to full auditoria in Nice - indeed extra dates were established to cater for audience demand. In the early 196os George Ballanchine for the Ballet de Paris and Kenneth MacMillan for the Royal Ballet in London had already adapted A Midsummer Night's Dream for the classical dance stage and, as we have seen, amongst a number of companies the Ballet de Hambourg had created another version for audiences in the 1970s. Thus, those attending performances of Le Songe might keep in reserve a number of expectations concerning the staging of narrative as well as looking forward to the visual seduction of the classical ballet. However, even here, if the delicacy and vivid richness of this production has won effusive admiration, there have also been examples of conditional praise. The reviewer for Le Monde, for example, submitted that Le Songe:

possède une texture théâtrale subtile, si fine qu'elle en devient presque trop légère, glissant entre les doigts comme les danseurs happés d'un bout à l'autre du plateau par une chorégraphie souple et ondoyante. De la verve certes, mais peu d'excès comme ceux, lyriques, puissamment délirants, que l'on savoure chez Shakespeare. 53

In general terms, however, in the comparison between the reception of these two productions, the challenges of Golden Hours (As You Like It) have often dominated journalistic accounts of the production.

We frequently encounter the voices of those hungry for more faithful, more easily navigable renderings of As You Like It through dance. The British broadsheet The Guardian, for example, found the production in Sadler's Wells contained 'little characterisation in the dancers' body language and their faces remain impassive throughout [...] too much of her choreography remains emotionally impenetrable'. ${ }^{54}$ In France in 2016, L'Alsace found the production 'lent et lancinant'. When the performance was accompanied by silence rather than Eno's music, this rendered 'd'autant plus sonore la régulière sortie de spectateurs'. 55 Here, the reviewer felt deprived of Shakespeare's text and of a recognizable dance vocabulary: 'Danse ou déplacement de danseurs? La grammaire de De Keersmaeker, à d'autres occasions si troublante, demeure ici indéchiffrable'. ${ }^{56}$ In a similar vein, The Financial Times found the Rosas production at Sadler's Wells 'punishingly glum' and 'still far, far too long at 125 interval free minutes'. 57 
Nonetheless, if The New York Times reviewed the première of Golden Hours in 2015, underlining that 'Ms. De Keersmaeker has rarely used narrative in her work', it also queried the relationship of the choreography to the chosen music ('a tangential relationship'). More generally, the review concluded that this production was still evolving, but at present constituted 'an oddly ambivalent enactment of Shakespeare's play that teeters uncertainly between abstractionism and literalism'. ${ }^{8}$

The differences in terms of production, adaptive undertaking, locale, audience and critical reception between Le Songe and Golden Hours remain thus clearly in evidence. Nonetheless, both dance projects specifically engaged on the chosen occasions at Montpellier and Nice in rendering Shakespearean comic texts through the medium of dance for twenty-first century, European festival spectators. As has been witnessed, the divergence of opinion between journalistic reviews returns again and again to the question of narrative expectation and, at this point, it might be timely to consider Lynsey McCulloch's reminder that 'Shakespeare's drama is not simply a source for narrative dance'.59 It may just be that critical and audience expectations need to be re-shaped to consider broader and sometimes more nuanced concepts of what Shakespearean adaptation might involve for the dance stage.

More generally, if Fraleigh has invited us to consider dance as invoking 'our understanding of what it means to move with a purpose - to formulate, remember, and repeat such movement - and to move either in relation to others or alone', it remains evident that both productions have continued to excite debate and, indeed, dispute. ${ }^{60}$ Le Songe draws upon some well-established expectations of the classical dance repertoire, while potentially unsettling such expectations with the inclusion of contemporary dance and some unanticipated musical choices. Conversely, the decisionmaking underpinning Golden Hours (As You Like It) for many reviewers has meant that its artistic undertaking can often appear occluded, unsatisfying or even alienating. Such considerations link directly with this discussion's point of departure - the implications of decision-making surrounding Shakespearean dance adaptation. Candace Feck has argued that the art of dance requires the careful deployment of all the critic's faculties to account fully for the appreciation of performance:

Writing about dance necessitates an active process of toggling between the lived experience of the writer and the phenomenon of viewing and writing. Calling on hearing and observation, opinion, memory and personal information, domain knowledge, association and self-awareness, the writer weaves an intricate and distinct tapestry of information. ${ }^{61}$

If the evidence of the many and various reviews relating to these two productions points to any conclusion, it must be that this 'toggling' is still to be fully resolved as an established critical practice.

\section{Concluding Thoughts}

Importantly, the dance critic Ingrid Pfandl-Buchegger has stressed that 'The body is what is left beyond the text' ${ }^{62}$, and in a broad philosophical investigation Michel de Certeau pondered the ways in which the body is deployed, rendered 'lisible' for ideological purposes by turning to the example of Shakespearean comedy: 
Ainsi Dromio, l'esclave, à son maître Antipholus d'Ephésè dans The Comedy of Errors: 'If the skin were parchment and the blows you gave were ink...' Shakespeare indiquait de la sorte le lieu premier de l'écriture et le rapport de maîtrise que la loi entretient avec son sujet par le geste de «lui faire la peau». Tout pouvoir, y compris celui du droit, se trace d'abord sur le dos de ses sujets. ${ }^{63}$

At the heart of the present discussion has been this interrogation of the expressive body and what relations it might and can have with a Shakespearean playscript, most particularly when the textual mass of the latter is mostly forsaken in performance. In such cases, to what extent are audiences asked to complete interpretative undertakings with prior knowledge ? To what extent does adaptation per se inevitably demand that we establish a relationship with the source text? If the latter is the case, must the Shakespearean origin inevitably govern, guide, circumscribe our appreciation of dance performance? Illuminatingly, in her own discussion of Bern:Ballett's production of Cathy Marston's Julia und Romeo, Lynsey McCulloch contends, 'I would suggest that any easy correlation between the text and the steps created by choreographers is impossible to delineate. [...] If choreographers refuse to make equivalencies of language and gesture, neither perhaps should critics' ${ }^{64}$

More generally, Ellen W. Goellner and Jacqueline Shea Murphy have recently highlighted the dichotomy in contemporary dance studies which often 'historically privileges verbal, particularly written, language over bodily or kinesthetic knowledge and language. [...] Dance writers are thus, even more than literary scholars, always confronted with the great difficulty of reducing the realities of motion to verbal formulas'. ${ }^{65}$ Thus, it is all too possible that some current undertakings of criticism may invest deeply in privileging unduly the Shakespearean verbum when considering dance adaptations of his work - an investment which could prove at odds with an equally important dimension of the bard's achievement, its challenging creativity. In this way, the critical undertaking of addressing dance itself has often been perceived as more thorny, nay intensely problematic. Randy Martin, for example, argues

where readers are said to perform, embody or enact what they receive, the question can at least be raised as to whether reading itself remains an appropriate term from which to generalize processes of cultural production and reception. The performer-audience relation seems closer than that of text and reader to approximating the object of history. As something that passes without a trace, like dance, the historical object lacks the stability of a text. Likewise, the conditions of history's production imply more participation than does the activity of interpretation or reading. This is not to suggest that dance cannot be read [...] but that reading must recognize the limits of its own approach to the object of analysis. [...] Dance has trouble staying still, and yet, one convention in writing about dance is to put it in its place. ${ }^{66}$

Finally, in perhaps one of the most vehement interventions that performance per se inevitably exceeds the grasp of criticism, Peggy Phelan has argued that 'To attempt to write about the undocumentable event of performance is to invoke the rules of the written document and thereby alter the event itself ${ }^{67}$ 
Few would disagree with Merce Cunningham's contention that 'it's difficult to talk about dance. It's not so much intangible as evanescent ' 68 and, more widely, dance critics repeatedly and seemingly inevitably continue to confront such vexed negotiations. If this debate is unlikely to be resolved in the near future, it is becoming apparent that the voices of dance historians and textual critics are multiplying in the field of published dance scholarship and continue to dynamise an already vibrant field with new lines of vision on a complex area of study. The present discussion follows the emphasis made by Melanie Bales and Karen Eliot that the appreciation of dance may 'profitably' benefit in adopting in certain instances 'concepts from cultural and literary studies', while acknowledging that in the past 'in their eagerness to adopt theoretical language from other disciplines, dance scholars have lost fluency in their own language'. ${ }^{69}$ Reviewing appreciations of both the chosen productions for festivals in the South of France, it seems that audiences (including critics and reviewers) may need to introduce greater suppleness in their understandings of Shakespearean adaptation. $A$ Midsummer Night's Dream or As You Like It offer intrigues, but also investigations into human response, human understanding and, equally importantly, the limits of human agency with the introduction of higher life forms such as the fairies or the god Hymen. Back in the years following the Second World War, Edwin Denby was surely right to point out that

Intellectually speaking, an interesting dance is a continuous discovery. The ideas it presents do not precede it, they are formed after one has perceived the movement. And because an interesting dance creates new ideas it is often not at all easy to understand nor in accord with what one would reasonably expect. ${ }^{\circ}$

This process of 'discovery', rather than recognition, in Shakespearean adaptation clearly still warrants much further attention than it is accorded at present in assessments of the discipline. 


\section{Acknowledgement}

The author would like to take this opportunity to express my gratitude to my colleagues Nathalie Vienne-Guerrin and Florence March at IRCL Montpellier 3 for their inspiring enthusiasm and support for this research project.

\section{Declaration of conflicting interests}

The author declared no potential conflicts of interest with respect to the research, authorship, and/or publication of this article.

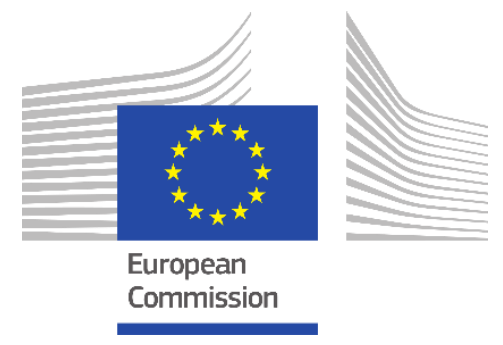

This project has received funding from the European Union's Horizon 2020 research and innovation programme under the Marie Sklodowska-Curie grant agreement $N^{\circ} 702104$

\section{Funding}

The author's disclosed receipt of the following financial support for the research, authorship, and/or publication of this article: This research was completed under the auspices of a Marie Sklodowska-Curie Research Fellowship (2016-18) at the Institut de Recherche sur la Renaissance, l'Âge Classique et les Lumières, Université Paul-Valéry, Montpellier III, France (MSCA no. 702104). 


\section{Bibliography}

Bales, Melanie \& Karen Eliot, 'Introduction', in Melanie Bales \& Karen Eliot (eds.), Dance on its own Terms. Histories and Methodologies (Oxford: Oxford University Press, 2013), pp. 4-11.

Béjart, Maurice, Un Instant dans la Vie d'Autrui. Mémoires (Paris: Flammarion, 1979).

Béjart, Maurice, La vie de qui ? Mémoires 2 (Paris: Flammarion, 1996).

Brissenden, Alan, Shakespeare and the Dance (London: Macmillan, 1981).

Brissenden, Alan, 'Shakespeare and Dance: Dissolving Boundaries', in Christa Jansohn, Lena Cowen Orlin and Stanley Wells (eds.), Shakespeare Without Boundaries. Essays in Honor of Dieter Mehl (Newark: University of Delaware Press, 2011), pp. 92-106.

Burt, Ramsay, Alien Bodies. Representations of modernity, 'race' and nation in early modern dance (London: Routledge, 1998).

Christout, Marie-Françoise, Le Ballet Occidental. Naissance et Métamorphoses XVI ${ }^{e}-X X^{e}$ siècles (Paris: Desjonquères, 1995).

Cunningham, Merce, The Dancer and the Dance, in conversation with Jacqueline Lesschaeve (New York: Marion Boyars, 1985).

Davies, Sir John, Nosce Teipsum ... Orchestra or A poeme of Dauncing (London: Augustine Matthewes, 1622).

Déléris, Alban, 'Play review: Golden Hours (As You Like It) adapted and choreographed by Anne Teresa for Rosas de Keersmaeker, Théâtre de l'Agora, Montpellier, 8 July 2015', Cahiers Élisabéthains 89 (2016), 119-121.

de Maisse, André Hurault, A Journal of all that was accomplished by Monsieur de Maisse Ambassador in England from King Henri IV to Queen Elizabeth Anno Domini 1597, trans. G. B. Harrison and R. A. Jones (London: Nonesuch Press, 1931).

Dempster, Elizabeth, 'Women Writing the Body: Let's Watch a Little How She Dances', in Ellen W. Goellner \& Jacqueline Shea Murphy (eds.), Bodies of the Text. Dance as Theory, Literature as Dance (New Brunswick NJ: Rutgers University Press, 1994), pp. 21-38.

Denby, Edwin, Looking at the Dance (New York: Pellegrini \& Cudahy, 1949).

Dumais-Lvowski, Christian (ed.), Anne Teresa de Keersmaeker - Rosas 2007-2017 (New Haven/Arles/Brussels: Yale University Press/Actes Sud/Mercatorfond, 2018).

Edgecombe, Rodney Stenning, 'Shakespeare, Ballet and Dance', in Mark Thornton Burnett et al (eds.), The Edinburgh Companion to Shakespeare and the Arts (Edinburgh: Edinburgh University Press, 2011), pp. 200-18.

Feck, Candace, 'What's in a Dance? The Complexity of Information in Writing about Dance', in Melanie Bales \& Karen Eliot (eds.), Dance on its own Terms. Histories and Methodologies (Oxford: Oxford University Press, 2013).

Fraleigh, Sondra Horton, Dance and the Lived Body. A Descriptive Aesthetics (Pittsburgh: University of Pittsburgh Press, 1987).

Goellner, Ellen W. \& Jacqueline Shea Murphy, 'Introduction: Movement Movements', in Ellen W. Goellner \& Jacqueline Shea Murphy (eds.), Bodies of the Text. Dance as Theory, Literature as Dance (New Brunswick NJ: Rutgers University Press, 1994), pp. 1-18.

Guisgand, Philippe, Les fils d'un entrelacs sans fin. La danse dans l'oeuvre d'Anna Teresa De Keersmaeker (Villeneuve d'Ascq: Presses Universitaires du Septentrion, 2007). 
Hiscock, Andrew, “Come, now a roundel and a fairy song”: Shakespeare's A Midsummer Night's Dream and the early modern invitation to the dance', Cahiers Élisabéthains (2018), 1-30.

Jonson, Ben, Ben Jonson: Selected Masques, ed. Stephen Orgel, (New Haven/London: Yale University Press, 1970).

Lévinas, Emmanuel, Humanisme de l'Autre Homme (Paris: Fata Morgana, 1972).

Lucian, Works, Eng. trans. A. M. Harmon, 8 vols. (London/Cambridge MA: William Heinemann Ltd./Harvard University Press, 1936).

Martin, Randy, Critical Moves. Dance Studies in Theory and Politics (Durham: Duke University Press, 1998).

McCulloch, Lynsey, 'Shakespeare and Dance', Literature Compass 13.2 (February 2016), 69-78.

McCulloch, Lynsey, "Here's that shall make you dance": Movement and Meaning in Bern:Ballett's Julia und Romeo', in Sarah Annes Brown, Robert I. Lublin and Lynsey McCulloch (eds.), Reinventing the Renaissance. Shakespeare and his Contemporaries in Adaptation and Performance (London: Palgrave MacMillan, 2013), pp. 255-268.

McCulloch, Lynsey \& Brandon Shaw (eds.), The Oxford Handbook of Shakespeare and Dance (Oxford: Oxford University Press, 2019).

McGowan, Margaret M., Dance in the Renaissance. European Fashion, French Obsession (New Haven/London: Yale University Press, 2008).

Nevile, Jennifer, The Eloquent Body. Dance and Humanist Culture in Fifteenth-Century Italy (Bloomington IN: Indiana University Press, 2004).

Noverre, Jean Georges, Letters on Dancing and Ballets, trans Cyril. W. Beaumont (New York: Dance Horizons Inc., 1966).

Pfandl-Buchegger, Ingrid, 'The Performing Body in Renaissance Literature and Dance', Anglia 132.1 (2014), 23-39.

Phelan, Peggy, Unmarked: The Politics of Performance (London: Routledge, 1993).

Pine, Adam and Olaf Kuhlke, 'Valorizing the many Different Spaces of Dances. Coopting the Cultural Choreography of Globalization', in Helen Thomas (ed.), Dance, Gender and Culture (Basingstoke: Macmillan, 1993), pp. 161-7.

Plato, Plato: Complete Works, ed. John M. Cooper et al (Indianapolis/Cambridge: Hackett Publishing Company, 1997).

Rancière, Jacques, Le spectateur émancipé (Paris: La Fabrique, 2008).

Rancière, Jacques, The Emancipated Spectator, trans. Gregory Elliott (London: Verso, 2009).

Shakespeare, William, A Midsummer Night's Dream, ed. Harold F. Brooks (London: Methuen \& Co./Arden Shakespeare, 1979).

Wharton, Robin, "There are no Mothers-in-Law in Ballet": "Doing" Shakespeare in Dance', Shakespeare Bulletin 23.3 (2005), 7-22.

\section{Websites}

Cathy Marston, choreographer for Bern:Ballett:

http://www.cathymarston.com/choreography2o11.html (accessed 6.11.19).

Critique DNA: http://www.lafilature.org/kernel/wp-content/uploads/2016/o1/GoldenHours-critique-DNA-samedi-23-avril-2016.pdf (accessed 22.8.18). 
L'Alsace: http://www.lafilature.org/kernel/wp-content/uploads/2016/o1/GoldenHours-critique-L-Alsace-samedi-23-avril-2016.pdf (accessed 23.8.18).

Le Figaro: http://www.lefigaro.fr/lefigaromagazine/2006/02/17/0100620060217ARTMAG90660-du rve au songe.php (accessed 22.8.18).

Le Monde: https://www.lemonde.fr/culture/article/2005/12/30/l-elegance-abstraitedu-songe 725804 3246.html (accessed 22.8.18).

Les Dernières Nouvelles d'Alsace: http://www.lafilature.org/kernel/wpcontent/uploads/2016/o1/Golden-Hours-critique-DNA-samedi-23-avril-2016.pdf (accessed 22.8.18).

Rosas Dance Company: http://www.rosas.be/fr/productions/362-golden-hours-as-youlike-it (accessed 22.8.18).

The Financial Times: https://www.ft.com/content/841e2cd8-e6o3-11e5-aogbIf8bod268c39 (accessed 22.8.18).

The Guardian: https://www.theguardian.com/stage/2016/aug/o4/the-taming-of-theshrew-review-bolshoi-ballet-jean-christophe-maillot (accessed 23.8.18). https://www.theguardian.com/stage/2016/mar/og/golden-hours-as-you-like-itreview-shakespeare (accessed 23.8.18).

The New York Times: https://www.nytimes.com/2015/o1/26/arts/dance/anne-teresade-keersmaekers-golden-hours-at-kaaitheater-in-brussels.html (accessed 23.8.18). 


\section{NOTES}

${ }^{1}$ Jean Georges Noverre, Letters on Dancing and Ballets, trans Cyril. W. Beaumont (New York: Dance Horizons Inc., 1966), p. 16 (Letter II).

${ }^{2}$ Noverre, Letters on Dancing and Ballets, p. 22 (Letter III).

3 Sondra Horton Fraleigh, Dance and the Lived Body. A Descriptive Aesthetics (Pittsburgh: University of Pittsburgh Press, 1987), p. 140.

${ }^{4}$ Randy Martin, Critical Moves. Dance Studies in Theory and Politics (Durham: Duke University Press, 1998), p. 46.

${ }_{5}$ Maurice Béjart, La vie de qui ? Mémoires 2 (Paris : Flammarion, 1996), p. 234. Translation: 'surpass the bounds of their art, gather together in [their works] all possibilities, break through the conventions of a single mode of expression to connect with the source of universal creativity. Leonardo da Vinci is one of the pioneers of such break-throughs. Shakespeare is much more than a playwright. Picasso goes far beyond painting in his modes as a painter. Orson Welles like Molière extend beyond [the arts of] the theatre and the cinema'. Unless otherwise indicated, all translations are my own.

${ }^{6}$ Elizabeth Dempster, 'Women Writing the Body: Let's Watch a Little How She Dances', in Ellen W. Goellner \& Jacqueline Shea Murphy (eds.), Bodies of the Text. Dance as Theory, Literature as Dance (New Brunswick NJ: Rutgers University Press, 1994), pp. 21-38 (p. 28).

7 Béjart's company established residence there in 1960, followed by the company led by Mark Morris in 1988. In 1992, De Keersmaeker began (and maintains) her association with the theatre but Rosas has not been in residence there since 2005 .

${ }^{8}$ See Marie-Françoise Christout, Le Ballet Occidental. Naissance et Métamorphoses XVI ${ }^{e}-X X^{e}$ siècles (Paris: Desjonquères, 1995), p. 162. Maillot has also created his own La Mégère Apprivoisée in 2014 for the Bolshoi Ballet. Interestingly in the context of this discussion, while The Guardian gave a warm reception to this production, the reviewer submitted one reservation that 'If there's a weakness in this Shrew it's the occasional confusions that arise from its highly compressed style of storytelling'. See https://www.theguardian.com/stage/2016/aug/o4/the-taming-of-the-shrew-review-bolshoi-ballet-jeanchristophe-maillot (accessed 23.8.18). Interestingly, Béjart underlines that for his own dance adaptation of A Midsummer Night's Dream he turned away from Mendelssohn's familiar score: 'C'était alors que je montai Le Songe d'une nuit d'hiver en campant les personnages de Shakespeare sur des partitions de Chopin, mariage qui n'était pas évident mais qui fonctionna'. See Maurice Béjart, Un Instant dans la Vie d'Autrui. Mémoires (Paris : Flammarion, 1979), p. 72. Translation: 'It was then that I staged Le Songe d'une nuit d'hiver placing Shakespearean characters onto scores by Chopin, a union which was not self-evident but which worked'. In this context, see also Cathy Marston's 2011 production for Bern:Ballett entitled Ein Winternachstraum (A $\quad$ Winter Night's $\quad$ Dream). http://www.cathymarston.com/choreography2011.html (accessed 6.11.19).

9 See http://www.lefigaro.fr/lefigaromagazine/2006/02/17/01006-20060217ARTMAG9o66odu rve au songe.php (accessed 22.8.18). Translation: 'The gestures are a mix of pantomime and dance, to which language is added sometimes. The whole is very heterogenous and does not lend itself to clear understanding'.

${ }^{10}$ See Floor Keersmaekers, 'Dans and its Traces. A conversation with Anne Maria de Keersmaeker', in Christian Dumais-Lvowski (ed.), Anne Teresa de Keersmaeker - Rosas 2007-2017 (New Haven/Arles/Brussels: Yale University Press/Actes Sud/Mercatorfond, 2018), n. p.

${ }^{11}$ In this context, see Lynsey McCulloch's illuminating discussion of the dance 'reworking of a lesserknown text' in terms of the Royal Ballet's staging of Christopher Wheedon's The Winter's Tale. McCulloch concludes tellingly with regard to more well-known Shakespearean narratives that 'One of the benefits of adapting Shakespeare's drama into dance is the ubiquity of his most performed works; the lack of verbal cues is not an issue when the plot is so familiar to an audience!'. See Lynsey McCulloch, 'Shakespeare and Dance', Literature Compass 13.2 (Feb 2016), 69-78 (p. 69). Nonetheless, it should be added that the most well-known plays in the corpus may generate alternative problems. As Klett points out in her discussion of Sir Kenneth MacMillan's dance adaptation of Hamlet as Sea of Troubles (1988), the reviews were mixed overall, with a principal focus on whether or not the piece made Hamlet intelligible and legible for its audiences'. See Elizabeth Klett, 'Measure in Everything: Adapting Hamlet to the Contemporary Dance Stage', in Lynsey McCulloch \& Brandon Shaw (eds.), The Oxford Handbook of Shakespeare and Dance, pp. 405-28 (p. 405). 
${ }^{12}$ Adam Pine and Olaf Kuhlke, 'Valorizing the many Different Spaces of Dances. Co-opting the Cultural Choreography of Globalization', in Helen Thomas (ed.), Dance, Gender and Culture (Basingstoke: Macmillan, 1993), pp. 161-7 (p. 163). Striking a more salutary note, Pine and Kuhlke add, 'This then imbues dance with a liberatory potential as distinctions between high-brow and low-brow dance are erased' (p. 163).

${ }^{13}$ Robin Wharton, "There are no Mothers-in-Law in Ballet": "Doing" Shakespeare in Dance', Shakespeare Bulletin 23.3 (2005), 7-22 (p. 12).

${ }^{14}$ Timaeus 40c. See Timaeus, trans. Donald J. Zeyl in Plato, Plato: Complete Works, ed. John M. Cooper et al (Indianapolis/Cambridge: Hackett Publishing Company, 1997), p. 1244. See also 'The Dance', where Lucian's danceophile voice, Lycinus, argues: "In fact, the concord of the heavenly spheres, the interlacing of the errant planets with the fixed stars, their rhythmic agreement and timed harmony, are proofs that Dance was primordial'. See 'The Dance', in Lucian, Works, Eng. trans. A. M. Harmon, 8 vols. (London/Cambridge MA: William Heinemann Ltd./Harvard University Press, 1936): V.221.

${ }^{15}$ See 'The Dance', in Lucian, Works, Eng. trans. A. M. Harmon, 8 vols. (London/Cambridge MA: William Heinemann Ltd./Harvard University Press, 1936): V.275.

${ }^{16}$ In terms of the potential of dance to effect ethical transformation in the onlooker, see: Florence Hazrat, "“The Wisdom of Your Feet": Dance and Rhetoric on the Shakespearean Stage', in McCulloch \& Shaw, The Oxford Handbook of Shakespeare and Dance (Oxford: Oxford University Press, 2019), pp. 217-236 (esp. pp. 219-20); Andrew Hiscock, "“Come, now a roundel and a fairy song": Shakespeare's A Midsummer Night's Dream and the early modern invitation to the dance', Cahiers Élisabéthains (2018), 1-30 (pp. 1315).

${ }_{17}$ Davies's poetic narrative then adds, 'But that her Art was somewhat lesse, she thought,/And on a meere ignoble subiect wrought'. See stanza 129 in Sir John Davies, Nosce Teipsum ... Orchestra or A poeme of Dauncing (London: Augustine Matthewes, 1622), sig. L2 ${ }^{\mathrm{v}}$. The first edition of the poem is published in 1596. For further discussion here, see, for example: Jennifer Nevile, The Eloquent Body. Dance and Humanist Culture in Fifteenth-Century Italy (Bloomington IN: Indiana University Press, 2004), p. $2 \mathrm{ff}$. ${ }^{18}$ Alan Brissenden, 'Shakespeare and Dance: Dissolving Boundaries', in Christa Jansohn, Lena Cowen Orlin and Stanley Wells (eds.), Shakespeare Without Boundaries. Essays in Honor of Dieter Mehl (Newark: University of Delaware Press, 2011), pp. 92-106 (p. 92). Interestingly, Brissenden adds that in the period 'it was the tragedies that first attracted dance makers' (p. 93).

${ }^{19}$ Iris Julia Bührle, 'Shakespeare Ballets in Germany. From Jean-Georges Noverre to John Neumeier', in McCulloch \& Shaw, The Oxford Handbook of Shakespeare and Dance, pp. 359-86 (p. 359).

${ }^{20}$ For further discussion here, see Hiscock, 'Come, now a roundel and a fairy song'.

${ }^{21}$ William Shakespeare, A Midsummer Night's Dream, ed. Harold F. Brooks (London: Methuen \& Co./Arden Shakespeare, 1979), pp. lv, cxxiii.

${ }^{22}$ Alan Brissenden, Shakespeare and the Dance (London: Macmillan, 1981), p. 41.

${ }^{23}$ Rodney Stenning Edgecombe, 'Shakespeare, Ballet and Dance', in Mark Thornton Burnett et al (eds.), The Edinburgh Companion to Shakespeare and the Arts (Edinburgh: Edinburgh University Press, 2011), pp. 200-18 (p. 204).

${ }^{24}$ Nevile, The Eloquent Body, p. 24.

${ }^{25}$ Elizabeth Klett, 'Measure in Everything: Adapting Hamlet to the Contemporary Dance Stage', in McCulloch \& Shaw, The Oxford Handbook of Shakespeare and Dance, p. 406.

${ }^{26}$ http://www.rosas.be/fr/productions/362-golden-hours-as-you-like-it (accessed 22.8.18). Translation:

'The dual title of the performance [...] provides the keys to understanding it'.

${ }^{27} \mathrm{http}: / / \mathrm{www}$.rosas.be/fr/productions/362-golden-hours-as-you-like-it (accessed 22.8.18). Translations: 'encounter'; 'an idyllic world'.

${ }^{28}$ See https://www.ft.com/content/841e2cd8-e603-11e5-aogb-1f8bod268c39 (accessed 22.8.18).

${ }^{29}$ See https://www.ft.com/content/841e2cd8-e603-11e5-aogb-1f8bod268c39 (accessed 22.8.18).

${ }^{30}$ Alban Déléris, 'Play review: Golden Hours (As You Like It) adapted and choreographed by Anne Teresa for Rosas de Keersmaeker, Théâtre de l'Agora, Montpellier, 8 July 2015', Cahiers Élisabéthains 89 (2016), $119-121$ (p. 120).

${ }^{31}$ http://www.rosas.be/fr/productions/362-golden-hours-as-you-like-it (accessed 22.8.18)

${ }_{32}$ See respectively: https://www.ft.com/content/841e2cd8-e603-11e5-aogb-1f8bod268c39 (accessed 22.8.18); $\quad$ http://www.lafilature.org/kernel/wp-content/uploads/2016/o1/Golden-Hours-critique-LAlsace-samedi-23-avril-2016.pdf (accessed 23.8.18). Translation: 'Gsports shoes, hats and hoodies'. 
du rve au songe.php (accessed 22.8.18). Translation: 'the costumes of the Athenians are all in the same grey hues'.

34 Cunningham, The Dancer and the Dance, p. 20.

35 Neumeier's choreography and stagings of A Midsummer Night's Dream in terms of discrete dance and musical worlds associated with the Athenians, fairies and mechanicals may clearly have had an important influence on Maillot's conceptualisation of Le Songe. For further discussion of Neumeier's corpus of work in terms of his production of the Dream, see Bührle, 'Shakespeare Ballets in Germany', p. 375.

36 See http://www.lefigaro.fr/lefigaromagazine/2006/02/17/01006-20060217ARTMAG9066odu rve au songe.php (accessed 22.8.18). Translation: 'Jean-Christophe Maillot has attacked a difficult ballet, A Midsummer Night's Dream. This undertaking is all the more sensitive as one of his colleagues, John Neumeier, had already taken it on, creating a little jewel of a production'.

$37 \quad$ See $\quad$ https://www.lemonde.fr/culture/article/2005/12/30/l-elegance-abstraite-dusonge $7258043246 . h t m l$ (accessed 22.8.18). Translation: 'in order to confirm once and for all his ability to draw together really stunning dance narratives - a talent which has become his signature -, JeanChristophe Maillot does not pull any punches [with Le Songe]'.

38 Margaret M. McGowan, Dance in the Renaissance. European Fashion, French Obsession (New Haven/London: Yale University Press, 2008), p. 28.

39 Pleasure Reconciled to Virtue (11. 240-3). See Ben Jonson, Ben Jonson: Selected Masques, ed. Stephen Orgel, (New Haven/London: Yale University Press, 1970), p. 171.

$4^{\circ}$ Emmanuel Lévinas, Humanisme de l'Autre Homme (Paris: Fata Morgana, 1972), pp. 26, 28. Translation: 'The spectator is actor. The line of vision should not be limited to the reception of the performance; simultaneously, the former is embedded in the performance being received. [...] We are not subject to the world and part of the world from two different points of view, rather, to coin an expression, we are subject to and part of the world at the same time. To perceive is to receive and to express at the same time through a kind of prolepsis'.

${ }^{41}$ Jacques Rancière, Le spectateur émancipé (Paris: La Fabrique, 2008), p. 9. Translation: 'We therefore need a different theatre, a theatre without spectators [...] Drama means action. Theatre is the place where an action is taken to its conclusion by bodies in motion in front of living bodies that are to be mobilized'. See Jacques Rancière, The Emancipated Spectator, trans. Gregory Elliott (London: Verso, 2009), p. 3.

${ }^{42}$ For further discussion here, see Hiscock, 'Come, now a roundel and a fairy song'.

43 André Hurault de Maisse, A Journal of all that was accomplished by Monsieur de Maisse Ambassador in England from King Henri IV to Queen Elizabeth Anno Domini 1597, trans. G. B. Harrison and R. A. Jones (London: Nonesuch Press, 1931), p. 95.

44 Edwin Denby, Looking at the Dance (New York: Pellegrini \& Cudahy, 1949), p. 11.

45 Martin, Critical Moves, p. 32.

46 https://www.theguardian.com/stage/2016/mar/og/golden-hours-as-you-like-it-review-shakespeare (accessed 23.8.18).

47 https://www.nytimes.com/2015/01/26/arts/dance/anne-teresa-de-keersmaekers-golden-hours-atkaaitheater-in-brussels.html (accessed 23.8.18).

48 http://www.lafilature.org/kernel/wp-content/uploads/2016/o1/Golden-Hours-critique-L-Alsacesamedi-23-avril-2016.pdf (accessed 23.8.18). Translation: 'one was expecting to see a narrative ballet [...] This would be to misunderstand the work radically. At the outset, you are advised to read carefully the synopsis of the play. This shrewd advice makes sense increasingly as the evening unfolds [...] doubtless, the spectators [...] who left the auditorium in waves had not followed this instruction'.

${ }^{49}$ Philippe Guisgand, Les fils d'un entrelacs sans fin. La danse dans l'oeuvre d'Anna Teresa De Keersmaeker (Villeneuve d'Ascq: Presses Universitaires du Septentrion, 2007), p. 51.

$5^{\circ}$ Rosalind was danced by a man and Jaques by a woman in this performance of Golden Hours. See http://www.lafilature.org/kernel/wp-content/uploads/2016/o1/Golden-Hours-critique-L-Alsace-samedi23-avril-2016.pdf (accessed 23.8.18). Translations: 'this Marivaux-like tale [i.e. of witty repartee and delicacy of conduct]'; 'Fortunate were those who worked out who was playing Rosalind [...] Fortunate were those who understood why Eno's music was being used [...] But the silence after Eno's music, was that still Eno?'.

${ }^{51}$ https://www.ft.com/content/841e2cd8-e603-11e5-aogb-1f8bod268c39?mhq5j=e3(accessed 22.8.18).

${ }^{2}$ Bührle, 'Shakespeare Ballets in Germany', p. 359. The problem remains even if new media are sought out to provide new solutions. Klett stresses that for the dance production of Stephen Mills' Hamlet (2000) 
for Ballet Austin in 2015, the latter's 'marketing department prepared a series of videos aimed at making the plot and characters intelligible'. See Klett, 'Measure in Everything', p. 407.

53 https://www.lemonde.fr/culture/article/2005/12/30/l-elegance-abstraite-du-songe 725804 3246.html (accessed 22.8.18). Translation: 'has a subtle theatrical surface, so gossamer-like that it almost becomes too airy, slipping through the fingers as the dancers are possessed from one end of the stage to the other by a supple, silky choreography. There is certainly spiritedness here, but little of the extravagance, lyrical, powerfully frenzied, that one relishes in Shakespeare's work'.

${ }^{54} \mathrm{https}$ ///www.theguardian.com/stage/2016/mar/og/golden-hours-as-you-like-it-review-shakespeare

55 http://www.lafilature.org/kernel/wp-content/uploads/2016/o1/Golden-Hours-critique-DNA-samedi23-avril-2016.pdf (accessed 22.8.18). Translations: 'slow and monotonous'; 'all the more audible the regular departure of spectators'. The departure of audience members was also commented upon by the French newspaper L'Alsace. See http://www.lafilature.org/kernel/wp-content/uploads/2016/o1/Golden-Hourscritique-L-Alsace-samedi-23-avril-2016.pdf (accessed 22.8.18).

${ }^{6}$ http://www.lafilature.org/kernel/wp-content/uploads/2016/o1/Golden-Hours-critique-DNA-samedi23-avril-2016.pdf (accessed 22.8.18). Translation: ‘dance or movements of dancers? De Keersmaeker's grammar, elsewhere so troubling, here remains undecodable'.

57 https://www.ft.com/content/841e2cd8-e603-11e5-aogb-1f8bod268c39?mhq5j=ez (accessed 22.8.18).

${ }_{58} \quad$ https://www.nytimes.com/2015/o1/26/arts/dance/anne-teresa-de-keersmaekers-golden-hours-atkaaitheater-in-brussels.html

${ }^{59}$ Lynsey McCulloch, 'Shakespeare and Dance', p. 69.

${ }^{60}$ Fraleigh, Dance and the Lived Body, p. 190.

${ }^{61}$ Candace Feck, 'What's in a Dance? The Complexity of Information in Writing about Dance', in Melanie Bales \& Karen Eliot (eds.), Dance on its own Terms. Histories and Methodologies (Oxford: Oxford University Press, 2013), pp. 411-30 (p. 414).

${ }^{62}$ Ingrid Pfandl-Buchegger, 'The Performing Body in Renaissance Literature and Dance', Anglia 132.1 (2014), 23-39 (p. 23).

${ }^{63}$ Michel de Certeau, 'Des Outils pour Écrire le Corps', Traverses 14-15 (April 1979), 3-14 (p. 3). Translation: 'And so Dromio, the slave, says to his master, Antipholus of Ephesus in The Comedy of Errors: 'If the skin were parchment and the blows you gave were ink...' Shakespeare was indicating in this way the first scene of writing and the relationship of domination that the law maintains with its subject through the action of 'trying to beat him down'. All power, including that of the law, expresses itself first of all on the backs of its subjects'.

${ }^{64}$ Lynsey McCulloch, “"Here's that shall make you dance”: Movement and Meaning in Bern:Ballett's Julia und Romeo', in Sarah Annes Brown, Robert I. Lublin and Lynsey McCulloch (eds.), Reinventing the Renaissance. Shakespeare and his Contemporaries in Adaptation and Performance (London: Palgrave MacMillan, 2013), pp. 255-268 (pp. 259, 260).

${ }_{55}$ Ellen W. Goellner \& Jacqueline Shea Murphy, 'Introduction: Movement Movements', in Ellen W. Goellner \& Jacqueline Shea Murphy (eds.), Bodies of the Text. Dance as Theory, Literature as Dance (New Brunswick NJ: Rutgers University Press, 1994), pp. 1-18 (p. 5).

${ }^{66}$ Martin, Critical Moves, p. 46. Ramsey Burt similarly acknowledges the pervasive criticism 'that has been levelled at some recent dance historical writing [...] that, in drawing on new theoretical approaches, the writers tend to neglect and marginalise the movement material that is its raison d'être'. See Ramsay Burt, Alien Bodies. Representations of modernity, 'race' and nation in early modern dance (London: Routledge, 1998), p. 9. In this context, see also: Melanie Bales \& Karen Eliot, 'Introduction', in Bales \& Eliot, Dance on its own Terms, pp. 4-11.

${ }^{67}$ Peggy Phelan, Unmarked: The Politics of Performance (London: Routledge, 1993), p. 148.

${ }^{68}$ Merce Cunningham, The Dancer and the Dance, in conversation with Jacqueline Lesschaeve (New York: Marion Boyars, 1985), p. 27.

${ }^{69}$ Bales \& Eliot, 'Introduction', p. 4.

${ }^{70}$ Denby, Looking at the Dance, p. 332. 